\title{
FAKTOR-FAKTOR UNTUK MENINGKATKAN PENERIMAAN PAJAK PERTAMBAHAN NILAI DI INDONESIA
}

\author{
Setiadi Alim Lim \\ Program Studi Akuntansi Politeknik Ubaya \\ Jalan Ngagel Jaya Selatan 169, Surabaya \\ Corresponding Author: setiadi.alim@gmail.com
}

\begin{abstract}
In the current era of the economic crisis caused by the Covid-19 virus pandemic, the performance of tax revenues worldwide is declining. Indonesia's tax revenues in 2020 experienced a significant decline, including Value Added Tax receipts which decreased by $14.89 \%$ compared to 2019. This study shows that in the current situation there are factors that support and hinder the increase in Value Added Tax revenues. Factors that support the increase in Value Added Tax revenue include: an increase in the fiscal deficit, a decrease in imports, a longstanding Value Added Tax, and the efficiency of tax administration by the government. Meanwhile, the factors that hindered the increase in Value Added Tax revenue were: negative Gross Domestic Product growth, decreased service consumption, decreased C-Value Added Tax efficiency. To increase the value added tax revenue, it is better not to increase the Value Added Tax rate, because most countries in ASEAN use a tariff of $10 \%$ or less, except in the Philippines where the rate is $12 \%$. If the rate of Value Added Tax is still increased, the maximum is not more than $12 \%$, and it is temporary in nature for now and will be returned to the original rate or lower after the economic crisis era has passed. Expansion of the object of Value Added Tax can be done, among others, by reducing goods and services that are exempt from the imposition of Value Added Tax, which are facilities freed, are not collected, and are borne by the government. If there is an expansion of the object of the imposition of Value Added Tax, then it should be done very selectively and not to be counterproductive by still giving exceptions to basic necessities that are needed by the community and services that have social objectives or based on international rules are exempt from being imposed. It is also hoped that the reduction in the number of exempt goods and services will not interfere with the economic activities of the community, let alone cause unrest in the community.
\end{abstract}

Keywords: Value Added Tax, tariff, object expansion, object exemption.

ABSTRAK
Pada era krisis ekonomi saat ini yang disebabkan pandemi Virus Covid-19,
kinerja penerimaan pajak di seluruh dunia menurun. Penerimaan pajak Indonesia 
tahun 2020 mengalami penurunan cukup besar, termasuk penerimaan Pajak Pertambahan Nilai yang turun sebesar 14,89\% dibandingkan tahun 2019. Studi ini menunjukkan bahwa pada situasi saat ini ditemukan adanya faktor-faktor yang mendukung dan menghambat peningkatan penerimaan Pajak Pertambahan Nilai. Faktor-faktor yang mendukung peningkatan penerimaan Pajak Pertambahan Nilai antara lain: meningkatnya defisit fiskal, turunnya impor, Pajak Pertambahan Nilai sudah lama diterapkan, dan efisiensi administrasi perpajakan yang dilakukan pemerintah. Sedangkan faktor-faktor yang menghambat peningkatan penerimaan Pajak Pertambahan Nilai antara lain: pertumbuhan Produk Domestik Bruto negatif, konsumsi jasa turun, efisiensi C-Pajak Pertambahan Nilai turun. Untuk meningkatkan penerimaan Pajak Pertambahan Nilai sebaiknya tidak menaikkan tarif Pajak Pertambahan Nilai, karena sebagian besar negara-negara di ASEAN menggunakan tarif $10 \%$ atau kurang, kecuali di Filipina yang tarifnya $12 \%$. Apabila tarif Pajak Pertambahan Nilai tetap dinaikkan, maka maksimum tidak lebih dari $12 \%$, serta sifatnya sementara untuk saat ini dan akan dikembalikan ke tarif semula atau lebih rendah setelah era krisis ekonomi berlalu. Perluasan objek Pajak Pertambahan Nilai dapat dilakukan antara lain dengan mengurangi barang dan jasa yang dikecualikan dari pengenaan Pajak Pertambahan Nilai, yang diberikan fasilitas dibebaskan, tidak dipungut, dan ditanggung pemerintah. Jika akan dilakukam perluasan objek pengenaan Pajak Pertambahan Nilai, maka hendaknya dilakukan dengan sangat selektif dan jangan sampai menjadi kontraproduktif dengan tetap memberikan pengecualian kepada barang-barang kebutuhan pokok yang dibutuhkan masyarakat banyak dan jasa-jasa yang mempunyai tujuan sosial atau berdasarkan kaidah internasional dikecualikan pengenaannya. Pengurangan jumlah barang dan jasa yang dikecualikan ini juga diharapkan jangan sampai mengganggu kegiatan perekonomian masyarakat apalagi menimbulkan keresahan di masyarakat.

Kata kunci: Pajak Pertambahan Nilai, tarif, perluasan objek, pengecualian objek.

\section{PENDAHULUAN}

Setiap tahun semua negara di dunia menyusun anggaran penerimaan dan belanja negara. Anggaran penerimaan dan belanja negara akan berisi proyeksi penerimaan dan belanja negara dalam 1 tahun. Belanja negara yang diproyeksikan umumnya mengikuti proyeksi dari penerimaan negara. Apabila penerimaan negara diproyeksikan besar, maka belanja negara diproyeksikan besar juga. Anggaran negara merupakan bagian terpenting dari keuangan pemerintah yang misi utamanya adalah membiayai barang publik (Hajdúchová et al., 2015). Salah satu sumber penerimaan negara berasal dari penerimaan pajak. Pajak adalah sumber pendapatan utama pemerintah (Onodugo and Anowor, 2013). Mankiw et al. (2009) menyatakan porsi terbesar dari anggaran pendapatan suatu negara bersumber dari pajak. Porsi total pajak harus mencapai 50\% sampai dengan $80 \%$ dari total penerimaan suatu negara. 
Salah satu bagian dari penerimaan pemerintah adalah penerimaan pajak, yang terbagi dalam tiga kategori utama, yaitu pajak langsung, pajak tidak langsung, dan kontribusi sosial (Hodzic and Celebi, 2017). Pajak langsung yang memberikan kontribusi terbesar terhadap penerimaan negara berasal dari Pajak Penghasilan. Sedangkan pajak tidak langsung dapat berupa Pajak Penjualan, Pajak Retail, Pajak Pertambahan Nilai (PPN), atau jenis pajak tidak langsung lainnya. Menurut (Kučerová, 2017) Pajak Pertambahan Nilai saat ini merupakan sistem pajak tidak langsung paling banyak digunakan di negara maju. Pajak Pertambahan Nilai di negara-negara berkembang juga merupakan jenis pajak tidak langsung paling populer dan paling banyak diimplementasikan.

Kontribusi Pajak Pertambahan Nilai terhadap penerimaan pajak keseluruhan setiap negara dari tahun ke tahun terus meningkat. Menurut OECD (2019) penerimaan pajak negara-negara anggota OECD terdiri dari: Pajak Pertambahan Nilai 20,2\%, Pajak Penghasilan Orang Pribadi 23,9\%, Pajak Penghasilan Badan (Korporasi) 9,3\%, Kontribusi Jaminan Sosial 26\%, Pajak Properti 5,8\%, Pajak Konsumsi lainnya 12,2\%, dan pajak lainnya 2,6\%. Charlet and Buydens (2012) menunjukkan Pajak Pertambahan Nilai secara global merupakan sumber pendapatan penting ketiga bagi pemerintah, setelah Kontribusi Jaminan Sosial (27\%) dan Pajak Penghasilan Orang Pribadi (25\%), tetapi jauh di atas Pajak Penghasilan Badan (8\%), Pajak Konsumsi Khusus (11\%), dan Pajak Properti $(5 \%)$. Mengingat besarnya kontribusi dari Pajak Pertambahan Nilai terhadap penerimaan pajak secara keseluruhan, maka kebijakan terkait dengan Pajak Pertambahan Nilai harus diambil dengan penuh kehati-hatian dan berdasarkan pertimbangan multi dimensional.

Besarnya pajak yang diterima oleh pemerintah diperoleh dari hasil perkalian tarif pajak dengan dasar pengenaan pajak. Hal ini juga berlaku terhadap Pajak Pertambahan Nilai yang besarnya ditentukan dari tarif Pajak Pertambahan Nilai dengan dasar pengenaan Pajak Pertambahan Nilai. Semakin besar tarif Pajak Pertambahan Nilai, maka semakin besar pula nilai Pajak Pertambahan Nilai. Demikian pula semakin besar dasar pengenaan Pajak Pertambahan Nilai, maka semakin besar juga nilai Pajak Pertambahan Nilai.

Pada era pandemi Covid-19 saat ini dengan dilakukannya berbagai pembatasan, aktivitas bisnis menurun drastis yang menyebabkan banyak unit usaha mengalami kerugian besar, bahkan banyak yang telah menutup usahanya. Penurunan aktivitas bisnis berpengaruh terhadap penerimaan pajak negara-negara di seluruh dunia. Target capaian penerimaan pajak yang telah diproyeksikan tidak dapat dipenuhi oleh hampir semua negara di seluruh dunia, termasuk di Indonesia. Untuk penerimaan pajak tahun 2020 Indonesia hanya bisa merealisasikan penerimaan pajak sebesar $89,25 \%$ dari jumlah penerimaan pajak yang ditargetkan. Hal ini di samping karena adanya penurunan aktivitas bisnis dari wajib pajak, juga disebabkan karena adanya beberapa insentif pajak yang diberikan oleh pemerintah kepada wajib pajak yang terdampak pandemi Covid-19.

Pandemi Covid-19 di Indonesia yang kasus pertamanya mulai ditemukan pada bulan Maret 2020 ternyata masih terus berlangsung pada tahun 2021 dan sampai dengan bulan Mei 2021 belum menunjukkan tanda-tanda akan mereda. Dalam hal ini target penerimaan pajak kembali terancam tidak akan tercapai lagi, 
bahkan ada kemungkinan persentase realisasinya dari target bisa lebih rendah dari pada tahun 2020. Menyikapi hal tersebut ada beberapa wacana kebijakan yang berkembang, salah satunya adalah menaikkan tarif dan perluasan objek Pajak Pertambahan Nilai. Apabila kebijakan ini diambil, maka ini akan merupakan sejarah baru dalam kebijakan implementasi Pajak Pertambahan Nilai di Indonesia. Karena sejak dilakukan reformasi perpajakan tahun 1983 Indonesia hanya menggunakan 1 tarif Pajak Pertambahan Nilai sebesar 10\% dan tidak pernah berubah. Penelitian ini akan menguraikam faktor-faktor apa yang dapat meningkatkan penerimaan Pajak Pertambahan Nilai dan apakah solusi menaikkan tarif dan perluasan objek Pajak Pertambahan Nilai adalah langkah yang tepat. Jika diambil kebijakan tersebut bagaimana konsekuensinya, mengingat Indonesia belum mempunyai pengalaman mengubah tarif Pajak Pertambahan Nilai.

\section{TINJAUAN PUSTAKA \\ Pajak Pertambahan Nilai}

Pajak Pertambahan Nilai telah diimplementasikan lebih dari 160 negara di seluruh dunia, termasuk di negara-negara berkembang (Gerard and Naritomi, 2018). Alavuotunki et al. (2019) menyatakan bahwa setelah penerapan Pajak Penghasilan Orang Pribadi dan pemotongan Pajak Penghasilan, Pajak Pertambahan Nilai menjadi salah satu inovasi kebijakan pajak yang paling penting. Pendapatan pajak di negara Uni Eropa $20 \%$ berasal dari Pajak Pertambahan Nilai (European Commission, 2006).

Menurut Gatawa et al. (2016) Pajak Pertambahan Nilai adalah pajak tidak langsung tipe khusus yang dibebankan pada setiap tahapan produksi dan distribusi barang dan jasa. Pajak Pertambahan Nilai termasuk jenis pajak multiple stage yaitu pajak yang dipungut pada beberapa tahapan, bukan hanya pada satu tahapan tertentu (single stage). Namun berbeda dengan jenis pajak tidak langsung lainnya Pajak Pertambahan Nilai hanya membebankan pajak atas tambahan nilai (value added) yang ditambahkan pada setiap tahapan produksi dan distribusi. Pengusaha yang melakukan penyerahan barang dan jasa yang wajib memungut Pajak Pertambahan Nilai dikenal dengan nama Pengusaha Kena Pajak (PKP),

Ada beberapa metode untuk menghitung besarnya Pajak Pertambahan Nilai terutang. Ebrill et al. (2001: 19-20) menyatakan ada 3 metode yang dapat dipakai untuk menghitung besarnya Pajak Pertambahan Nilai terutang, yaitu: (i) Invoice Credit Method; (ii) Substracion Method; (iii) Addition Method. Masing-masing metode ini memiliki kelebihan dan kekurangan, namun di antara ketiga metode ini yang paling banyak digunakan adalah Invoice Credit Method. Ebrill et al. (2001: 83-85) juga menyatakan secara umum ada 8 kategori barang dan jasa yang dikecualikan yaitu: produk pertanian dan input pertanian utama, bahan bakar, semen, angkutan penumpang, layanan di mana masalah cakupan dan penggunaan daftar "positif" dan "negatif" muncul, barang-barang budaya dan jasa lainnya (seperti buku dan surat kabar, dan kegiatan nonkomersial organisasi keagamaan), kegiatan yang dibiayai bantuan, dan barang modal (pada dasarnya barang modal yang diimpor). 


\section{Faktor-Faktor yang Berpengaruh pada Penerimaan Pajak Pertambahan Nilai}

Bogetic and Hassan (1993) menemukan tarif dan dasar pengenaan Pajak Pertambahan Nilai berpengaruh positif terhadap penerimaaan Pajak Pertambahan Nilai, sedangkan dispersi tarif Pajak Pertambahan Nilai berpengaruh negatif terhadap penerimaaan Pajak Pertambahan. Godin and Hindriks (2015) menyatakan beberapa faktor utama yang berpengaruh positif pada penerimaan pajak yaitu: pertumbuhan ekonomi, efisiensi pemerintah, keterbukaan perdagangan, dan ukuran tarif pajak.

Sarmento (2016) meneliti 4 kelompok variabel yang diduga mempengaruhi penerimaan Pajak Pertambahan Nilai, dan 3 di antaranya hasil penelitiannya seperti terlihat pada Tabel 1 yaitu: 1) variabel Pajak Pertambahan Nilai (tarif Pajak Pertambahan Nilai, tarif minimum, dan tarif implisit); 2) variabel lingkungan ekonomi (impor, jasa, dan defisit fiskal sebagai persentase dari PDB);

3) Efisiensi administrasi perpajakan (diukur dengan efisiensi C-PPN, jumlah tahun penerapan Pajak Pertambahan Nilai, dan efisiensi Pemerintah).

Tabel 1

Variabel yang Mempengaruhi Penerimaan Pajak Pertambahan Nilai (PPN)

\begin{tabular}{|c|l|c|c|}
\hline No. & Variabel Independen & $\begin{array}{c}\text { Variabel Dependen: } \\
\text { Penerimaan PPN }\end{array}$ & $\begin{array}{c}\text { Variabel Dependen: } \\
\text { Penerimaan PPN } \\
\text { Sebagai \% PDB }\end{array}$ \\
\hline 1. & Tarif PPN & Positif & Positif \\
\hline 2. & Tarif Minimum & Positif & Tidak Signifikan \\
\hline 3. & Tarif Implisit & Positif & Positif \\
\hline 4. & Impor & Negatif & Negatif \\
\hline 5. & Jasa & Positif & Positif \\
\hline 6. & Defisit & Positif & Negatif \\
\hline 7. & Efisiensi C-PPN & Positif & Positif \\
\hline 8. & Lamanya Penerapan & Positif & Positif \\
\hline 9. & Efisiensi Pemerintah & Positif & Positif \\
\hline 10. & Korupsi Rendah & &
\end{tabular}

Sumber: Sarmento (2016)

Variabel Pajak Pertambahan Nilai yang berpengaruh terhadap penerimaan Pajak Pertambahan Nilai terdiri dari tarif Pajak Pertambahan Nilai, termasuk tarif implisit, dan tarif minimum. Dalam mendesain Pajak Pertambahan Nilai yang akan diimplementasikan, salah satu faktor yang harus diputuskan dengan penuh pertimbangan dan kehati-hatian adalah masalah penetapan tarif Pajak Pertambahan Nilai. Suatu negara harus mempertimbangkan dengan baik menggunakan tarif Pajak Pertambahan Nilai tunggal artinya menggunakan 1 tarif Pajak Pertambahan Nilai atau menggunakan lebih dari 1 tarif. Ebrill et al. (2001: 69) menunjukkan persentase jumlah negara menggunakan 1 sampai dengan 6 tarif Pajak Pertambahan Nilai di luar tarif Pajak Pertambahan Nilai 0\% seperti terlihat pada Tabel 2. 
Tabel 2

Persentase Negara yang Menggunakan 1-6 Tarif Pajak Pertambahan Nilai (Di luar Tarif Pajak Pertambahan Nilai 0\%)

\begin{tabular}{|c|l|c|}
\hline No. & \multicolumn{1}{|c|}{$\begin{array}{c}\text { Jumlah Tarif yang } \\
\text { Digunakan }\end{array}$} & $\begin{array}{c}\text { Persentase Negara yang } \\
\text { Menggunakan }\end{array}$ \\
\hline 1. & 1 Tarif & $53 \%$ \\
\hline 2. & 2 Tarif & $23 \%$ \\
\hline 3. & 3 Tarif & $13 \%$ \\
\hline 4. & 4 Tarif & $9 \%$ \\
\hline 5. & 5 Tarif & $0 \%$ \\
\hline 6. & 6 Tarif & $1 \%$ \\
\hline
\end{tabular}

Sumber: Tabulasi dari IMF Staf dalam Ebrill et al. (2001: 69)

Bogetic and Hassan (1993) menyatakan negara-negara yang menggunakan tarif Pajak Pertambahan Nilai tunggal cenderung mempunyai pendapatan Pajak Pertambahan Nilai lebih besar dari pada negara-negara yang menggunakan banyak tarif Pajak Pertambahan Nilai. Ebrill et al. (2001: 78-79) menyatakan dukungan penggunaan 1 tarif didasarkan pada pengalaman kesulitan administrasi dan kepatuhan yang terkait dengan tarif berganda, karena terbuka peluang untuk melakukan kecurangan. Otoritas pajak juga lebih sulit melakukan administrasi perpajakan karena harus mengelompokkan objek Pajak Pertambahan Nilai yang dikenakan tarif berbeda. Mengenai besarnya tarif Pajak Pertambahan Nilai termasuk tarif implisit yang ideal untuk diterapkan belum ada ukuran pasti. Setiap negara menggunakan tarif yang berbeda-beda tergantung kondisi ekonomi dan kebijakan otoritas masing-masing negara. Besarnya tarif Pajak Pertambahan Nilai rata-rata per kelompok negara periode 2017-2021 seperti terlihat pada Tabel 3. Kemudian pada Tabel 4 nampak tarif Pajak Pertambahan Nilai dari 9 negara ASEAN.

Tabel 3

Tarif Pajak Pertambahan Nilai Rata-Rata per Kelompok Negara Periode Tahun 2017-2021

\begin{tabular}{|c|l|c|c|c|c|c|c|}
\hline No. & Kelompok & \multicolumn{5}{|c|}{ Tarif Rata-rata Pajak Pertambahan Nilai } \\
\cline { 3 - 8 } & & $\mathbf{2 0 1 7}$ & $\mathbf{2 0 1 8}$ & $\mathbf{2 0 1 9}$ & $\mathbf{2 0 2 0}$ & $\mathbf{2 0 2 1}$ & $\begin{array}{c}\text { Rata- } \\
\text { Rata }\end{array}$ \\
\hline 1. & Afrika & 15,36 & 15,55 & 15,72 & 15,95 & 16,00 & 15,72 \\
\hline 2. & Amerika & 13,07 & 13,29 & 13,27 & 13,34 & 13,34 & 13,26 \\
\hline 3. & Asia & 12,32 & 11,96 & 11,54 & 11,83 & 11,60 & 11,85 \\
\hline 4. & Uni Eropa & 21,52 & 21,52 & 21,52 & 21,52 & 21,46 & 21,51 \\
\hline 5. & Eropa & 20,10 & 20,13 & 19,86 & 19,87 & 19,80 & 19,95 \\
\hline 6. & Amerika Latin & 13,31 & 13,53 & 13,51 & 13,59 & 13,59 & 13,51 \\
\hline 7. & Amerika Utara & 5,00 & 5,00 & 5,00 & 5,00 & 5,00 & 5,00 \\
\hline 8. & Oceania & 11,92 & 12,33 & 12,33 & 12,33 & 12,33 & 12,25 \\
\hline 9. & OECD & 19,18 & 19,17 & 19,23 & 19,23 & 19,12 & 19,19 \\
\hline 10. & Global & 15,53 & 15,53 & 15,45 & 15,55 & 15,42 & 15,50 \\
\hline
\end{tabular}

Sumber: KPMG (2021) 


\section{Tabel 4}

Tarif Pajak Pertambahan Nilai atau Pajak Sejenisnya di Negara ASEAN-9

\begin{tabular}{|c|l|c|}
\hline No. & \multicolumn{1}{|c|}{ Nama Negara } & Tarif Pajak \\
\hline 1. & Filipina & $12 \%$ \\
\hline 2. & Indonesia & $10 \%$ \\
\hline 3. & Kamboja & $10 \%$ \\
\hline 4. & Laos & $10 \%$ \\
\hline 5. & Malaysia & $5 \%$ \\
\hline 6. & Myanmar & $7 \%$ \\
\hline 7. & Singapura & $7 \%$ \\
\hline 8. & Thailand & $10 \%$ \\
\hline 9. & Vietnam & $\mathbf{9 \%}$ \\
\hline & Rata-rata $*$ (barang) & dan $6 \%$ jasa) \\
\hline
\end{tabular}

Sumber: Lim (2020)

*) Rata-rata dengan tidak memasukkan tarif jasa di Malaysia

Bogetic and Hassan (1993) menyatakan rata-rata tarif Pajak Pertambahan Nilai di seluruh dunia berpengaruh positif terhadap Produk Domestik Bruto (PDB) dengan rasio produktivitas pendapatan rata-rata 0,35 persen dari Produk Domestik Bruto. Menurut Sarmento (2016) terdapat hubungan positif antara tarif Pajak Pertambahan Nilai dan jumlah pendapatan Pajak Pertambahan Nilai, yang menunjukkan selama beberapa tahun terakhir negara-negara telah menaikkan tarif pajaknya dalam menghadapi kendala fiskal. Tetapi hasil yang berbeda ditemukan Hajdúchová et al. (2015) yang menemukan porsi Pajak Pertambahan Nilai terhadap total penerimaan pajak, setelah adanya kenaikan tarif Pajak Pertambahan Nilai sebesar 1\% tidak meningkat, malah sebaliknya, turun dari di atas 55\% menjadi kurang dari 53\% yang berarti tarif Pajak Pertambahan Nilai berpengaruh negatif terhadap penerimaan Pajak Pertambahan Nilai. Kemudian Alm and ElGanainy (2013) menyatakan kenaikan tarif Pajak Pertambahan Nilai sebesar satu poin persentase mengarah pada sekitar satu persen penurunan tingkat konsumsi agregat dalam jangka pendek dan penurunan yang lebih besar dalam jangka panjang, yang berarti penurunan pula jumlah penerimaan Pajak Pertambahan Nilai.

Menurut Dijkstra (2013) efek kenaikan tarif Pajak Pertambahan Nilai untuk barang normal, baik efek pendapatan maupun efek substitusi bekerja ke arah yang sama. Karena baik efek pendapatan maupun efek substitusi adalah negatif sehubungan dengan kenaikan Pajak Pertambahan Nilai, produsen harus selalu menanggung sebagian dari kenaikan Pajak Pertambahan Nilai. Kučerová (2017) menemukan pelanggan menganggap kenaikan tarif Pajak Pertambahan Nilai sebagai faktor yang sangat negatif, menyebabkan kenaikan harga barang sehingga menurunkan daya beli dan taraf hidup. Teori saat ini menunjukkan kenaikan Pajak Pertambahan Nilai permanen yang diumumkan sebelumnya dikombinasikan dengan pengurangan Pajak Penghasilan (atau pemotongan Pajak Pertambahan Nilai sementara) akan memungkinkan kebijakan fiskal untuk meningkatkan 
pengeluaran konsumsi, khususnya, belanja konsumen untuk barang tahan lama (D'Acunto et al. 2020).

Tarif minimum Pajak Pertambahan Nilai umumnya diimplementasikan untuk barang dan jasa tertentu yang bersifat strategis. Karena hanya dikenakan tarif minimum yang di bawah tarif normal Pajak Pertambahan Nilai, maka kebijakan penggunaan tarif minimum Pajak Pertambahan Nilai akan menyebabkan timbulnya erosi pada penerimaan Pajak Pertambahan Nilai. Menurut Hodzic and Celebi (2017) Efisiensi C-Pajak Pertambahan Nilai (ECPPN) dihitung dari jumlah penerimaan Pajak Pertambahan Nilai dibagi dengan hasil perkalian jumlah konsumsi final rumah tangga dengan tarif Pajak Pertambahan Nilai dikalikan $100 \%$.

\section{METODE PENELITIAN}

Penelitian ini merupakan penelitian yang bersifat kualitatif deskriptif (Creswell, 1994) dengan tujuan mendapatkan informasi faktor-faktor yang mempengaruhi penerimaan Pajak Pertambahan Nilai di Indonesia serta kemungkinan kenaikan tarif dan perluasan objek Pajak Pertambahan Nilai. Data yang digunakan dalam penelitian diperoleh melalui studi kepustakaan yang terutama diperoleh melalui Undang-Undang Nomor 6 Tahun 1983 tentang Ketentuan Umum dan Tata Cara Perpajakan sebagaimana telah beberapa kali diubah terakhir dengan Undang-Undang Nomor 16 Tahun 2009, Undang-Undang Nomor 8 Tahun 1983 tentang Pajak Pertambahan Nilai dan Pajak Penjualan atas Barang Mewah sebagaimana telah beberapa kali diubah terakhir dengan UndangUndang Nomor 42 Tahun 2009, dan peraturan pelaksana lainnya terkait dengan implementasi Pajak Pertambahan Nilai di Indonesia. Di samping itu data yang akan dianalisis juga berasal dari data Badan Pusat Statistik tentang Produk Domestik Bruto Indonesia Tahun 2016-2020, data dari Direktorat Jenderal Pajak tentang realisasi penerimaan pajak tahun 2016-2020 per jenis pajak, serta data Bank Indonesia dan Kementerian Keuangan Republik Indonesia.

\section{Data Penelitian}

\section{Pelaksanaan Pajak Pertambahan Nilai di Indonesia}

Pajak Pertambahan Nilai di Indonesia mulai diimplementasikan pertama kali pada tanggal 1 April 1985. Pajak Pertambahan Nilai di Indonesia diatur berdasarkan Undang-Undang Nomor 8 Tahun 1983 sebagaimana telah beberapa kali diubah terakhir dengan Undang-Undang Nomor 42 Tahun 2009. Pajak Pertambahan Nilai di Indonesia menggunakan 1 tarif Pajak Pertambahan Nilai sebesar 10\% mulai 1 April 1985 sampai dengan saat ini bulan Mei 2021. Untuk kegiatan ekspor dikenakan Pajak Pertambahan Nilai dengan tarif $0 \%$, dan untuk kegiatan impor dikenakan tarif Pajak Pertambahan Nilai sebesar $10 \%$.

Pajak Pertambahan Nilai dikenakan terhadap penyerahan Barang Kena Pajak dan Jasa Kena Pajak. Di dalam pasal 4A ayat (2) disebutkan barang-barang yang digolongkan sebagai bukan Barang Kena Pajak yaitu: (a) barang hasil pertambangan atau hasil pengeboran yang diambil langsung dari sumbernya; (b) barang kebutuhan pokok yang sangat dibutuhkan oleh rakyat banyak; (c) makanan dan minuman yang disajikan di hotel, restoran, rumah makan, warung, dan 
sejenisnya, meliputi makanan dan minuman baik yang dikonsumsi di tempat maupun tidak, termasuk makanan dan minuman yang diserahkan oleh usaha jasa boga atau katering; dan (d) uang, emas batangan, dan surat berharga. Semua barang yang tidak termasuk bukan Barang Kena Pajak atas penyerahannya akan dikenakan Pajak Pertambahan Nilai sebesar 10\%.

Kemudian pada pasal 4A ayat (3) diatur mengenai jasa-jasa yang digolongkan sebagai bukan Jasa Kena Pajak yaitu: (a) jasa pelayanan kesehatan medis; (b) jasa pelayanan sosial; (c) jasa pengiriman surat dengan perangko; (d) jasa keuangan; (e) jasa asuransi; (f) jasa keagamaan; (g) jasa pendidikan; (h) jasa kesenian dan hiburan; (i) jasa penyiaran yang tidak bersifat iklan; (j) jasa angkutan umum di darat dan di air serta jasa angkutan udara dalam negeri yang menjadi bagian yang tidak terpisahkan dari jasa angkutan udara luar negeri; (k) jasa tenaga kerja; (l) jasa perhotelan; (m) jasa yang disediakan oleh pemerintah dalam rangka menjalankan pemerintahan secara umum; (n) jasa penyediaan tempat parkir; (o) jasa jasa telepon umum dengan menggunakan uang logam; (p) jasa pengiriman uang dengan wesel pos; dan (q) jasa boga atau katering. Semua jasa yang tidak termasuk bukan Jasa Kena Pajak atas penyerahannya akan dikenakan Pajak Pertambahan Nilai sebesar $10 \%$.

Administrasi perpajakan di Indonesia, baik untuk penyetoran dan pelaporan telah dilaksanakan dengan menggunakan aplikasi berbasis online. Untuk Pajak Pertambahan Nilai administrasinya dilakukan dengan menggunakan aplikasi $e$ Faktur dan e-billing.

\section{Produk Domestik Bruto Indonesia}

Perkembangan perekonomian suatu negara dapat terlihat dari Produk Domestik Bruto (PDB). Secara umum kondisi perekonomian Indonesia dalam 5 tahun terakhir relatif stabil, kecuali untuk tahun 2020 yang mengalami penurunan karena adanya pandemi Covid-19. Produk Domestik Bruto Indonesia untuk periode 2016-2020 terlihat pada Tabel 5 (dalam miliar rupiah) dan Laju Pertumbuhan Produk Domestik Bruto pada Tabel 6.

\section{Tabel 5}

\section{Produk Domestik Bruto Indonesia Menurut Komponen Pengeluaran Atas Dasar Harga Konstan 2010 Periode 2016-2020} (dalam miliar rupiah)

\begin{tabular}{|c|l|r|r|r|r|r|}
\hline No. & \multicolumn{1}{|c|}{ Uraian } & \multicolumn{1}{c|}{$\mathbf{2 0 1 6}$} & $\mathbf{2 0 1 7}$ & \multicolumn{1}{c|}{$\mathbf{2 0 1 8}$} & $\mathbf{2 0 1 9} *$ ) & $\mathbf{2 0 2 0} * *$ ) \\
\hline 1. & Konsumsi Rumah Tangga & $5.126 .308,0$ & $5.379 .628,6$ & $5.651 .456,3$ & $5.936 .399,5$ & $5.780 .218,1$ \\
\hline 2. & Konsumsi LNPRT & $105.362,3$ & $112.664,4$ & $122.969,8$ & $136.026,6$ & $130.193,3$ \\
\hline 3. & Konsumsi Pemerintah & $774.304,5$ & $790.756,4$ & $828.876,6$ & $855.930,8$ & $872.558,3$ \\
\hline 4. & PMTB & $3.041 .584,7$ & $3.228 .763,0$ & $3.444 .310,3$ & $3.597 .664,1$ & $3.419 .704,2$ \\
\hline 5. & Perubahan Inventori & $133.400,1$ & $126.883,6$ & $197.369,6$ & $129.953,8$ & $51.334,1$ \\
\hline 6. & Ekspor Barang dan Jasa & $1.971 .182,6$ & $2.146 .564,5$ & $2.286 .394,9$ & $2.266 .679,3$ & $2.092 .038,0$ \\
\hline 7. & Impor Barang dan Jasa & $1.818 .133,2$ & $1.964 .819,2$ & $2.203 .269,9$ & $2.040 .354,1$ & $1.740 .166,3$ \\
\hline & TOTAL PDB $* * *)$ & $\mathbf{9 . 4 3 4 . 6 1 3 , 4}$ & $\mathbf{9 . 9 1 2 . 9 2 8 , 1}$ & $\mathbf{1 0 . 4 2 5 . 8 5 1 , 9}$ & $\mathbf{1 0 . 9 4 9 . 0 3 7 , 8}$ & $\mathbf{1 0 . 7 2 2 . 4 4 2 , 7}$ \\
\hline
\end{tabular}

Sumber: Badan Pusat Statistik (2021: 45)

Keterangan: *) sementara **) sangat sementara $* * *)$ bukan penjumlahan 1-7 
Tabel 6

Laju Pertumbuhan Produk Domestik Bruto Indonesia Atas Dasar Harga Konstan 2010 Menurut Komponen Pengeluaran (persen) Periode 2016-2020

\begin{tabular}{|c|l|c|c|c|c|c|}
\hline No. & \multicolumn{1}{|c|}{ Uraian } & $\mathbf{2 0 1 6}$ & $\mathbf{2 0 1 7}$ & $\mathbf{2 0 1 8}$ & $\mathbf{2 0 1 9} *)$ & $\mathbf{2 0 2 0} * *)$ \\
\hline 1. & Konsumsi Rumah Tangga & $5,01 \%$ & $4,94 \%$ & $5,05 \%$ & $5,04 \%$ & $-2,63 \%$ \\
\hline 2. & Konsumsi LNPRT & $6,64 \%$ & $6,93 \%$ & $9,15 \%$ & $10,62 \%$ & $-4,29 \%$ \\
\hline 3. & Konsumsi Pemerintah & $-0,14 \%$ & $2,12 \%$ & $4,82 \%$ & $3,26 \%$ & $1,94 \%$ \\
\hline 4. & PMTB & $4,47 \%$ & $6,15 \%$ & $6,68 \%$ & $4,45 \%$ & $-4,95 \%$ \\
\hline 5. & Ekspor Barang dan Jasa & $-1,66 \%$ & $8,90 \%$ & $6,51 \%$ & $-0,86 \%$ & $-7,70 \%$ \\
\hline 6. & Impor Barang dan Jasa & $-2,41 \%$ & $8,07 \%$ & $12,14 \%$ & $-7,39 \%$ & $-14,71 \%$ \\
\hline & TOTAL PDB ***) & $\mathbf{5 , 0 3 \%}$ & $\mathbf{5 , 0 7 \%}$ & $\mathbf{5 , 1 7 \%}$ & $\mathbf{5 , 0 2 \%}$ & $\mathbf{- 2 , 0 7 \%}$ \\
\hline
\end{tabular}

Sumber: Badan Pusat Statistik (2021: 48)

Keterangan: *) sementara **) sangat sementara ***) bukan penjumlahan 1-7

\section{Penerimaan Pajak Indonesia}

Penerimaan Pajak di Indonesia untuk 5 tahun terakhir adalah sebagai seperti terlihat pada Tabel 7.

Tabel 7

Laporan Realisasi Pendapatan Pajak Tahun 2016-2020 (dalam miliar rupiah)

\begin{tabular}{|c|l|r|r|r|r|r|}
\hline No. & \multicolumn{1}{|c|}{ Uraian } & \multicolumn{1}{|c|}{$\mathbf{2 0 1 6}$} & \multicolumn{1}{c|}{$\mathbf{2 0 1 7}$} & \multicolumn{1}{c|}{$\mathbf{2 0 1 8}$} & \multicolumn{1}{c|}{$\mathbf{2 0 1 9}$} & \multicolumn{1}{c|}{$\mathbf{2 0 2 0}$} \\
\hline 1. & PPh Non Migas & $\mathbf{6 3 0 . 1 1 7 , 8 0}$ & $\mathbf{5 9 6 . 4 7 9 , 2 4}$ & $\mathbf{6 8 5 . 2 7 6 , 4 4}$ & $\mathbf{7 1 3 . 1 1 0 , 5 0}$ & $\mathbf{5 6 0 . 6 7 0 , 0 0}$ \\
\hline 2. & PPN terdiri dari: & $\mathbf{3 9 6 . 0 3 4 , 3 2}$ & $\mathbf{4 6 3 . 5 2 6 , 8 6}$ & $\mathbf{5 2 0 . 3 8 3 , 4 4}$ & $\mathbf{5 1 5 . 9 5 4 , 7 2}$ & $\mathbf{4 3 9 . 1 4 0 , 0 0}$ \\
\hline & - PPN Dalam Negeri & $272.997,09$ & $314.341,26$ & $333.920,09$ & $344.429,65$ & $298.840,00$ \\
\hline & - PPN Impor & $122.774,62$ & $149.034,79$ & $186.394,64$ & $171.362,69$ & $140.300,00$ \\
\hline & - PPN Lainnya & 262,61 & 150,81 & 68,71 & 162,38 & - \\
\hline 3. & PPnBM terdiri dari: & $\mathbf{1 6 . 1 7 1 , 1 4}$ & $\mathbf{1 7 . 1 9 6 , 1 7}$ & $\mathbf{1 2 . 7 6 9 , 7 0}$ & $\mathbf{1 5 . 6 0 5 , 6 8}$ & $\mathbf{9 . 2 5 0 , 0 0}$ \\
\hline & - PPnBM Dalam Negeri & $11.810,03$ & $13.292,14$ & $12.794,67$ & $10.847,41$ & $6.250,00$ \\
\hline & - PPnBM Impor & $4.295,38$ & $3.796,75$ & 4.108 .01 & $4.725,16$ & $3.000,00$ \\
\hline & - PPnBM Lainnya & 65,73 & 107,28 & $(24,97)$ & 33,11 & - \\
\hline 4. & PBB & $\mathbf{1 9 . 4 4 3 , 2 3}$ & $\mathbf{1 6 . 7 7 0 , 3 5}$ & $\mathbf{1 9 . 4 4 4 , 5 2}$ & $\mathbf{2 1 . 1 4 5 , 9 0}$ & $\mathbf{2 0 . 9 5 0 , 0 0}$ \\
\hline 5. & BPHTB & - & $\mathbf{1 , 2 2}$ & - & - & - \\
\hline 6. & Pajak Lainnya & $\mathbf{8 . 1 0 4 , 9 0}$ & $\mathbf{6 . 7 3 8 , 4 8}$ & $\mathbf{6 . 6 3 0 , 3 1}$ & $\mathbf{7 . 6 7 7 , 4 7}$ & $\mathbf{6 . 7 9 0 , 0 0}$ \\
\hline 7. & PPh Migas & $\mathbf{3 6 . 0 9 8 , 6 5}$ & $\mathbf{5 0 . 3 1 5 , 7 5}$ & $\mathbf{6 4 . 7 0 9 , 7 9}$ & $\mathbf{5 9 . 1 6 4 , 8 8}$ & $\mathbf{3 3 . 1 8 0 , 0 0}$ \\
\hline & TOTAL PDB & $\mathbf{1 . 0 7 1 . 8 8 7 , 2 4}$ & $\mathbf{1 . 1 0 2 . 7 2 7 , 8 0}$ & $\mathbf{1 . 2 5 0 . 8 0 1 , 8 3}$ & $\mathbf{1 . 3 3 2 . 6 5 9 , 1 5}$ & $\mathbf{1 . 0 6 9 . 9 8 0 , 0 0}$ \\
\hline
\end{tabular}

Sumber: Direktorat Jenderal Pajak (2016, 2017, 2018, 2019, 2020)

\section{HASIL PENELITIAN DAN PEMBAHASAN}

Data dari Tabel 7 menunjukkan penerimaan Pajak Pertambahan Nilai di Indonesia tahun 2020 sebesar Rp. 439.140 miliar menurun sebesar Rp. 76.814,72 miliar (14,89\%) jika dibandingkan dengan tahun 2019 yang berjumlah Rp. 515.954,72 miliar. Penerimaan Pajak Penjualan atas Barang Mewah juga mengalami penurunan dari jumlah Rp. 15.605,68 miliar pada tahun 2019 menjadi Rp. 9.250 miliar atau turun sebesar Rp. 6.355,68 miliar (40,73\%). Penurunan sangat signifikan penerimaan Pajak Pertambahan Nilai diindikasikan karena adanya pandemi Virus Covid-19 yang telah menurunkan aktivitas perekonomian. Hal ini ditunjukkan data Tabel 5 yang menunjukkan bahwa Produk Domestik Bruto Indonesia pada tahun 2020 sebesar Rp. 10.722.442,7 miliar lebih kecil dari Produk Domestik Bruto tahun 2019 sebesar Rp. 10.949.037,8 miliar atau dapat disebut bahwa ekonomi Indonesia pada tahun 2020 mengalami kontraksi atau 
penurunan dengan tingkat pertumbuhan negatif yaitu sebesar $(2,07 \%)$ setelah beberapa tahun sebelumnya tumbuh positif di kisaran 5\%. Penurunan penerimaan Pajak Pertambahan Nilai tahun 2020 yang disebabkan oleh penurunan pertumbuhan Produk Domestik Bruto sudah sesuai dengan temuan Godin and Hindriks (2015).

Bank Indonesia (2021: xvii) menunjukkan bahwa defisit fiskal (APBN) dalam tahun 2018 dan 2019 masing-masing sebesar (1,82\%) dan (2,2\%). Sedangkan pada tahun 2020 realisasi sementara defisit fiskal menurut Kementerian Keuangan Republik Indonesia (2021a: 9) sebesar (6,1\%). Jumlah defisit fiskal tahun 2020 ini jauh lebih tinggi dari pada tahun 2018 dan 2019. Meningkatnya defisit fiskal menurut temuan Sarmento (2016) seharusnya meningkatkan penerimaan Pajak Pertambahan Nilai. Namun di dalam tahun 2020 meningkatnya defisit fiskal malah menurunkan penerimaan Pajak Pertambahan Nilai, tetapi penurunan ini dapat juga disebabkan faktor-faktor lainnya.

Tabel 6 menunjukkan impor barang dan jasa Produk Domestik Bruto tahun 2020 mengalami penurunan sekitar 14,71\%, sedangkan penerimaan Pajak Pertambahan Nilai turun. Hal ini tidak sesuai dengan temuan Sarmento (2016) yang menyatakan impor mempunyai pengaruh negatif terhadap penerimaan Pajak Pertambahan Nilai, tetapi ada kemungkinan pula bahwa pengaruh negatif tersebut dinetralisir dengan variabel lainnya yang berpengaruh positif lebih besar. Untuk data jasa tidak semuanya bisa didapatkan, tetapi jenis jasa yang dikonsumsi rumah tangga menunjukkan penurunan riil pada tahun 2020 sebesar $(14,62 \%)$ dibandingkan tahun 2019 (Badan Pusat Statistik, 2021: 56). Untuk ekspor dan impor jasa juga mengalami penurunan dalam tahun 2020 dibandingkan tahun 2019 yaitu masing-masing turun sebesar $(48,69 \%)$ dan $(34,66 \%)$ (Badan Pusat Statistik, 2021: 68-70). Hal ini sesuai dengan temuan Sarmento (2016) bahwa ada pengaruh positif antara jasa dengan penerimaan Pajak Pertambahan Nilai.

Indonesia sudah menerapkan Pajak Pertambahan Nilai mulai 1 April 1985 kurang lebih sudah 36 tahun sampai dengan saat ini. Karena Indonesia sudah lama menerapkan Pajak Pertambahan Nilai seharusnya sesuai temuan Sarmento (2016) hal ini akan mendukung peningkatan penerimaan Pajak Pertambahan Nilai. Untuk efisiensi C-Pajak Pertambahan Nilai tahun 2019 dan 2020 dapat dihitung sebagai berikut: (i) EC-PPN $2019=($ Rp. 515.954,72: $(10 \%$ x Rp. 8.965.837,4) $) \times 100 \%=$ 57,55\%; (ii) EC-PPN $2020=($ Rp. 439.140,00 : $(10 \%$ x Rp. 8.900.011,1) $) \times 100 \%$ $=49,34 \%$. Perhitungan ini menunjukkan ada penurunan efisiensi C-Pajak Pertambahan Nilai dan memang terjadi penurunan penerimaan Pajak Pertambahan Nilai tahun 2020 dibandingkan dengan tahun 2019. Hal ini sesuai dengan temuan Sarmento (2016). Administrasi Pajak Pertambahan Nilai telah dilakukan menggunakan aplikasi yang berbasis online, sehingga Pengusaha Kena Pajak tidak perlu secara fisik datang ke Kantor Pelayanan Pajak, sehingga kerja dari pemerintah yaitu Direktorat Jenderal Pajak dapat dilakukan secara sangat efisien. Hal ini sesuai dengan temuan Sarmento (2016) dan Godin and Hindriks (2015) mendukung peningkatan penerimaan Pajak Pertambahan Nilai.

Sarmento (2016) menunjukkan beberapa tahun terakhir negara-negara telah menaikkan tarif pajaknya dalam menghadapi kendala fiskal. Dalam situasi pandemi Covid-19 saat ini penerimaan Pajak Pertambahan Nilai dan Pajak 
Penjualan atas Barang Mewah di Indonesia tahun 2020 turun dengan sangat tajam masing-masing sebesar 14,89\% dan 40,73\% jika dibandingkan dengan tahun 2019, maka apa yang disampaikan Sarmento (2016) di atas perlu dikaji artinya menaikkan tarif Pajak Pertambahan Nilai di Indonesia. Tarif Pajak Pertambahan Nilai saat ini sebesar $10 \%$ sudah cukup moderat, artinya tidak terlalu tinggi dan tidak terlalu rendah. Jika dibandingkan dengan tarif Pajak Pertambahan Nilai ratarata Asia dan dunia pada tahun 2021 masing-masing sebesar 11,60\% dan 15,42\% tarif Pajak Pertambahan Nilai di Indonesia masih lebih rendah dan masih dimungkinkan untuk dinaikkan. Tetapi jika melihat tarif Pajak Pertambahan Nilai dan pajak sejenisnya negara-negara ASEAN-9 pada Tabel 4 di mana tarif rataratanya sebesar 9\%, dengan maksimal sebesar $12 \%$ di Filipina, kemudian di Kamboja, Laos, Malaysia, dan Vietnam sebesar 10\%, di Singapura dan Thailand sebesar 7\%, serta di Myanmar sebesar 5\%, maka seharusnya tarif Pajak Pertambahan Nilai di Indonesia tidak perlu dinaikkan, mengingat negara-negara di ASEAN sebagai kompetitor Indonesia dalam menarik investor asing kebanyakan menggunakan tarif tidak lebih dari 10\%, kecuali Filipina.

Di samping itu selain temuan dari Sarmento (2016) dan Godin and Hindriks (2015) yang menyatakan kenaikan tarif Pajak Pertambahan Nilai berpengaruh positif terhadap penerimaan Pajak Pertambahan Nilai, ada juga temuan dari Hajdúchová et al. (2015) dan Alm and El-Ganainy (2013) yang menyatakan bahwa tarif Pajak Pertambahan Nilai berpengaruh negatif terhadap penerimaan Pajak Pertambahan Nilai. Kebijakan untuk menaikkan tarif Pajak Pertambahan Nilai juga kemungkinan besar akan menaikkan harga barang dan jasa yang dijual, karena penjual umumnya akan menaikkan harga jual dengan tambahan kenaikan sebagian atau seluruhnya tarif Pajak Pertambahan Nilai (Dijkstra, 2013). Kenaikan harga barang dan jasa akan menyebabkan menurunnya daya beli dan taraf hidup masyarakat (Kučerová, 2017).

Namun jika tetap diambil kebijakan untuk menaikkan tarif Pajak Pertambahan Nilai di Indonesia, maka hendaknya tarif yang baru maksimal sama dengan tarif tertinggi yang saat ini diterapkan di negara ASEAN yaitu di Filipina, sebesar $12 \%$. Di samping itu untuk menaikkan daya beli masyarakat perlu diberikan fasilitas tambahan untuk Pajak Penghasilan Orang Pribadi, selain fasilitas Pajak Penghasilan Pasal 21 dan Pajak Penghasilan Final sesuai Peraturan Pemerintah Nomo 23 Tahun 2018 ditanggung pemerintah. Hal ini sesuai dengan apa yang disarankan oleh D'Acunto et al. (2020) bahwa kenaikan tarif Pajak Pertambahan Nilai sebaiknya dikombinasikan dengan pengurangan Pajak Penghasilan agar daya beli masyarakat tetap terjaga. Dengan demikian konsumsi masyarakat dapat dipertahankan dan pertumbuhan Produk Domestik Bruto tetap terjaga.

Penggunaan tarif tunggal Pajak Pertambahan Nilai hendaknya tetap dipertahankan, karena seperti diungkapkan Bogetic and Hassan (1993) penggunaan tarif tunggal Pajak Pertambahan Nilai akan mempunyai penerimaan Pajak Pertambahan Nilai lebih besar. Di samping itu penggunaan multi tarif akan menimbulkan banyak kesulitan administrasi dan masalah kepatuhan (Ebrill et al., 2001: 78-79). Hal lain yang dapat dilakukan adalah memperluas objek Pajak Pertambahan Nilai agar dasar pengenaan pajak meningkat dan ini berarti 
meningkatkan pula penerimaan Pajak Pertambahan Nilai. Jumlah barang dan jasa yang bukan Barang Kena Pajak dan bukan Jasa Kena Pajak seperti diatur dalam pasal 4A ayat (2) dan ayat (3) Undang-Undang Nomor 8 Tahun 1983 sebagaimana telah beberapa kali diubah terakhir dengan Undang-Undang Nomor 42 Tahun 2009 dikurangi. Demikian pula fasilitas Pajak Pertambahan Nilai dibebaskan, tidak dipungut, dan ditanggung pemerintah dikurangi. Alternatif lain adalah mengenakan tarif Pajak Pertambahan Nilai minimum kepada sebagian besar barang dan jasa yang saat ini bukan Barang Kena Pajak dan bukan Jasa Kena Pajak serta barang dan jasa yang mendapat fasilitas Pajak Pertambahan Nilai dibebaskan, tidak dipungut, dan ditanggung pemerintah. Tetapi jika itu dilakukan berarti menggunakan tarif Pajak Pertambahan Nilai lebih dari 1 dan dapat berakibat kesulitan administrasi dan menarik perhatian para pelaku kecurangan pajak untuk melakukan fraud. Namun hendaknya tetap dipertahankan pengecualian pengenaan Pajak Pertambahan Nilai untuk barang-barang kebutuhan pokok yang dibutuhkan masyarakat banyak, jasa pelayanan kesehatan medis, jasa pelayanan sosial, jasa keuangan, jasa asuransi, jasa keagamaan, jasa pendidikan, jasa kesenian dan hiburan, jasa penyiaran yang tidak bersifat iklan, jasa angkutan umum di darat dan di air serta jasa angkutan udara dalam negeri yang menjadi bagian yang tidak terpisahkan dari jasa angkutan udara luar negeri, jasa yang disediakan oleh pemerintah dalam rangka menjalankan pemerintahan secara umum yang sebagian besar merupakan barang dan jasa yang dikecualikan menurut Ebrill et al. (2001: 83-85).

Secara keseluruhan dalam situasi saat ini memang banyak faktor yang kurang mendukung peningkatan penerimaan Pajak Pertambahan Nilai di Indonesia, antara lain: pertumbuhan Produk Domestik Bruto negatif, konsumsi jasa turun, efisiensi C-Pajak Pertambahan Nilai turun. Sedangkan faktor yang mendukung peningkatan penerimaan Pajak Pertambahan Nilai antara lain: meningkatnya defisit fiskal, turunnya impor, Pajak Pertambahan Nilai sudah lama diterapkan, dan efisiensi administrasi perpajakan yang dilakukan pemerintah.

\section{SIMPULAN}

Dalam situasi pandemi Covid-19 penerimaan pajak di Indonesia pada tahun 2020 mengalami penurunan yang cukup besar, termasuk dari sektor penerimaan Pajak Pertambahan Nilai yang turun sebesar 14,89\% dibandingkan tahun 2019. Studi yang dilakukan menunjukkan ada banyak faktor yang kurang mendukung peningkatan penerimaan Pajak Pertambahan Nilai, antara lain: pertumbuhan Produk Domestik Bruto negatif, konsumsi jasa turun, efisiensi C-Pajak Pertambahan Nilai turun. Di samping itu juga ada banyak faktor yang mendukung peningkatan penerimaan Pajak Pertambahan Nilai yaitu meningkatnya defisit fiskal, turunnya impor, Pajak Pertambahan Nilai sudah lama diterapkan, dan efisiensi administrasi perpajakan yang dilakukan pemerintah.

Tarif Pajak Pertambahan Nilai di Indonesia sebesar 10\% sudah sangat moderat, mengingat rata-rata tarif Pajak Pertambahan Nilai dan pajak sejenisnya di 9 negara ASEAN adalah 9\%, dan kebanyakan negara-negara di ASEAN menggunakan tarif $10 \%$ atau kurang, kecuali di Filipina yang tarifnya $12 \%$. Perluasan objek Pajak Pertambahan Nilai dapat dilakukan antara lain dengan 
mengurangi barang dan jasa yang dikecualikan dari pengenaan Pajak Pertambahan Nilai, yang diberikan fasilitas dibebaskan, tidak dipungut, dan ditanggung pemerintah. Peningkatan tarif Pajak Pertambahan Nilai dan perluasan objek pengenaan Pajak Pertambahan Nilai harus dilakukan dengan sangat hati-hati, agar tidak menimbulkan gejolak ekonomi dan bisa meningkatkan jumlah penerimaan Pajak Pertambahan Nilai.

\section{SARAN}

Sebaiknya tarif Pajak Pertambahan Nilai tidak dinaikkan. Jika dinaikkan, maka kenaikan itu hendaknya jangan sampai lebih besar dari $12 \%$ yaitu tarif Pajak Pertambahan Nilai di Filipina yang merupakan negara ASEAN dengan tarif Pajak Pertambahan Nilai tertinggi. Hendaknya kenaikan ini bersifat sementara, sehingga apabila kondisi krisis ekonomi saat ini yang disebabkan oleh pandemi Virus Covid-19 telah berlalu, tarif Pajak Pertambahan Nilai disesuaikan kembali ke tarif asal sebesar $10 \%$ atau yang lebih rendah.

Perluasan objek Pajak Pertambahan Nilai dapat dilakukan dengan sangat selektif dan jangan sampai menjadi kontraproduktif dengan tetap memberikan pengecualian kepada barang-barang kebutuhan pokok yang dibutuhkan masyarakat banyak dan jasa-jasa yang mempunyai tujuan sosial atau berdasarkan kaidah internasional dikecualikan pengenaannya. Pengurangan jumlah barang dan jasa yang dikecualikan ini juga diharapkan jangan sampai mengganggu kegiatan perekonomian masyarakat apalagi menimbulkan keresahan di masyarakat.

\section{DAFTAR PUSTAKA}

Alavuotunki, Kaisa, Mika Haapanen, and Jukka Pirttilä. 2019. The Effects of The Value-Added Tax on Revenue and Inequality. The Journal of Development Studies, Vol. 55, No.4, pp. 490-508.

Alm, James and Asmaa El-Ganainy. 2013. Value-Added Taxation and Consumption. International Tax and Public Finance, Vol. 20, pp. 105-128.

Badan Pusat Statistik. 2021. Produk Domestik Bruto Indonesia Menurut Pengeluaran 2016-2020. Badan Pusat Statistik. Jakarta.

Bank Indonesia. 2021. Laporan Perekonomian Indonesia 2020: Bersinergi Membangun Optimisme Pemulihan Ekonomi. Bank Indonesia. Jakarta.

Bogetic, Zeljko and Fareed Hassan. 1993. Determinants of Value-Added Tax Revenue: A Cross-Section Analysis. World Bank Policy Working Paper (WPS 1203).

Charlet, Alain and Stéphane Buydens. 2012. The OECD International VAT/GST Guidelines: Past and Future Developments. World Journal of VAT/GST Law, Vol. 1, Issue 2, pp. 175-184.

Creswell, John. 1994. Research Design: Qualitative and Quantitative Approaches. Sage Publications. London. 
D'Acunto, Francesco, Daniel Hoang, and Michael Weber. 2020. Unconventional Fiscal Policy to Exit The COVID-19 Crisis. VOX, CEPR Policy Portal (https://voxeu.org).

Dijkstra, Jonneke. 2013. The influence of The VAT Increase on Consumer Prices. Master Thesis in Economics and Taxation.

Direktorat Jenderal Pajak. 2016. Laporan Tahunan 2016. Direktorat Jenderal Pajak. Jakarta.

Direktorat Jenderal Pajak. 2017. Laporan Tahunan 2017. Direktorat Jenderal Pajak. Jakarta.

Direktorat Jenderal Pajak. 2018. Laporan Tahunan 2018. Direktorat Jenderal Pajak. Jakarta.

Direktorat Jenderal Pajak. 2019. Laporan Tahunan 2019. Direktorat Jenderal Pajak. Jakarta.

Direktorat Jenderal Pajak. 2020. Laporan Kinerja Direktorat Jenderal Pajak 2020. Direktorat Jenderal Pajak. Jakarta.

Ebrill, Liam, Michael Keen, Jean-Paul Bodin, and Victoria Summers, 2001, The Modern VAT, International Monetary Fund, Washington D.C.

European Commission. 2006. Structures of The Taxation Systems in The European Union: 1995-2004. DOC/TAXUD E4/2006/DOC/3201.

Gatawa, Nasiru Mukhtar, Haruna Mohammed Aliero, and Abdullahi Muhammad Aishatu. 2016. Evaluating The Impact of Value Added Tax on The Economic Growth of Nigeria. Journal of Accounting and Taxation. Vol. 8, No. 6, pp. 5965.

Gerard, Francois and Joana Naritomi. 2018. Value Added Tax in Developing Countries: Lessons from Recent Research, IGC Growth Brief Series 015, International Growth Centre, London.

Godin, Mattéo and Jean Hindriks. 2015. A Review of Critical Issues on Tax Design and Tax Administration in A Global Economy and Developing Countries. Core Discussion Paper 28.

Hajdúchová, Iveta, Mariana Sedliačiková, and Igor Viszlai. 2015. Value-added Tax Impact on The State Budget Expenditures and Incomes. Procedia Economics and Finance, Vol. 34, pp. 676-681.

Hodzic, Sabina and Hulya Celebi. 2017. Value-Added Tax and Its Efficiency: EU-28 and Turkey. UTMS Journal of Economics, Vol. 8, Issue 2, pp. 79-90.

Kementerian Keuangan Republik Indonesia. 2021. APBN Kita 2020: Kinerja dan Fakta. Edisi Januari 2021. Kementerian Keuangan Republik Indonesia. Jakarta. 
Kementerian Keuangan Republik Indonesia. 2021a. Konferensi Pers Realisasi Pelaksanaan APBN TA 2020 (Angka Bersifat Sementara Menunggu Hasil Realisasi Final Diaudit LKPP Tahun 2020). Kementerian Keuangan Republik Indonesia. Jakarta.

KPMG. https://home.kpmg/xx/en/home/services/tax/tax-tools-and-resources/taxrates-online/indirect-tax-rates-table.html. diakses 1 Juni 2021, Pukul 14:24.

Kučerová, Vladimíra. 2017. VAT and Its Influence on Buying Behaviour. Institute of Economic Research Working Papers, No. 52/2017. Toruń, Poland.

Lim, Setiadi Alim. 2020. Implementasi Pajak Pertambahan Nilai di Indonesia: Suatu Studi Perbandingan di Negara-Negara ASEAN-9. Jurnal Bisnis Perspektif, Vol. 12, No. 1, pp. 27-46.

Mankiw, N. Gregory, Matthew Weinzierl, and Danny Yagan. 2009. Optimal Taxation in Theory and Practice. Journal of Economic Perspectives, Vol. 23, No. 4, pp. 147-174.

OECD. 2019. Reveue Statistics 2019: Tax Revenue Trends in The OECD.

Onodugo, Vincent A. and Oluchukwu F. Anowor. 2013. An Evaluation of The Contribution of Value Added Tax (VAT) to Resource Mobilization in Nigeria. European Journal of Business and Management, Vol. 5, No. 6, pp 35-41.

Sarmento, Joaquim. 2016. The Determinants of Value Added Tax Revenues in The European Union. The European Journal of Management Studies, Vol. 21, Issue 2, pp. 79-99.

Undang-Undang Nomor 6 Tahun 1983 tentang Ketentuan Umum dan Tata Cara Perpajakan sebagaimana telah beberapa kali diubah terakhir dengan UndangUndang Nomor 16 Tahun 2009.

Undang-Undang Nomor 8 Tahun 1983 tentang Pajak Pertambahan Nilai dan Pajak Penjualan atas Barang Mewah sebagaimana telah beberapa kali diubah terakhir dengan Undang-Undang Nomor 42 Tahun 2009

Zhong, Hao. 2016. The Choice of China's Business Tax to Value Added Tax Reform: The Traditional VAT Model or The Modern GST Model?. A Thesis Submitted in Partial Fulfilment of The Requirements For The Degree of Master of Commerce in Accounting. University of Canterbury. 